\title{
REPROVAÇÃO EM ESCOLAS DE PRESTÍGIO
}

DIANA MANDELERT

\section{RESUMO}

Este artigo teve como objetivo saber como acontece a reprovação naquelas escolas que são consideradas e avaliadas como as melhores do país, onde alunos e professores encontram uma estrutura pedagógico-administrativa que funciona a seu favor. Foram selecionadas duas escolas que obtiveram notas excelentes no Enem de 2005 e 2006. Realizou-se um mapeamento de quando as escolas reprovam, quantos alunos são reprovados, o que acontece com os alunos reprovados e, finalmente, como as escolas recompõem as turmas com as sucessivas reprovações que ocorrem durante uma geração escolar. Foi possível observar que a qualidade de ensino, como uma combinação de desempenho e fluxo, não ocorre nessas escolas. A excelência escolar é efetivada por meio de uma intensa seletividade que se opera de diversas formas, sendo a repetência uma das mais importantes.

PALAVRAS-CHAVE REPROVAÇÃO • ELITES • CLASSE SOCIAL • QUALIDADE DO ENSINO. 


\title{
RESUMEN
}

Este artículo tuvo como objetivo saber cómo acontece la reprobación en aquellas escuelas consideradas y evaluadas como las mejores del país, en las que alumnos y profesores encuentran una estructura pedagógico-administrativa que funciona a su favor. Se seleccionaron dos escuelas que obtuvieron excelente en el Enem de 2005 y 2006. Se realizó un mapeo de cuándo las escuelas reprueban, cuántos alumnos son reprobados, qué acontece con ellos y, finalmente, cómo las escuelas recomponen los grupos con las sucesivas reprobaciones que ocurren con una generación escolar. Se observó que la calidad de la enseñanza, como una combinación de desempeño y flujo, no ocurre en esas escuelas. La excelencia escolar se efectiviza a través de una inmensa selectividad que opera de diversas formas, siendo la repitencia una de las más importantes.

PALABRAS CLAVE REPETICIÓN • ELITES • CLASE SOCIAL • CALIDAD DE LA EDUCACIÓN.

\begin{abstract}
This article aims to investigate how failing happens in those schools which are considered and evaluated as the best in the country, where students and teachers find a teaching and administrative structure that works in their favor. We selected two schools that achieved excellence in the 2005 and 2006 Enem exam. We mapped when schools failed students, how many students failed, what happened to the students who failed and finally how schools recomposed classes due to the successive failings that occur during a school generation. It was observed that the quality of teaching as a combination of performance and flow does not occur in these schools. Academic excellence is achieved through an intense selectivity that takes place in various forms, student failing being one of the most important.
\end{abstract}

KEYWORDS GRADE REPETITION • ELITES • SOCIAL CLASS • TEACHING QUALITY. 


\section{INTRODUÇÃO}

O tema da reprovação é sabidamente antigo e de grande importância social e política no Brasil. Os altos níveis de reprovação e sua persistência na história da educação brasileira fizeram com que Sergio Costa Ribeiro afirmasse, em 1991, que no Brasil existiria uma verdadeira "pedagogia da repetência". Esta, portanto, não poderia ser atribuída às diferenças de "dons e aptidões" dos alunos ou às suas "deficiências culturais”, interpretações que predominaram até a década de 1970 . Segundo essa tese, a reprovação estaria fortemente integrada "às práticas escolares".

$\mathrm{Na}$ análise da qualidade da educação básica no Brasil, o problema é tão relevante quanto os problemas de desempenho, pois se considera que é na conjugação de desempenho e fluxo que está inserido o conceito de qualidade. O Índice de Desenvolvimento da Educação Básica (Ideb) foi criado pelo Instituto Nacional de Estudos e Pesquisa (Inep) para as escolas públicas justamente pensando nisso. Considerou-se que qualidade de ensino não seria compatível com a exclusão e a pré-seleção, daí a importância da relação entre fluxo e desempenho escolar. 
Esses altos índices de reprovação ocorrem em todas as classes sociais, pois como o próprio Costa Ribeiro afirma: “a repetência não é privilégio da escola dos pobres e muito menos da escola pública" (1996, p. 61). Ainda que muito pouco estudada, a reprovação também acontece nas escolas particulares, só que de forma diferenciada. Um dos poucos estudos sobre o assunto é de Mello Souza e Valle Silva (1994), com dados da Pesquisa Nacional por Amostra de Domicílios (PNAD) de 1999, quando observaram que, nas escolas particulares, as taxas de repetência são mais altas no segundo segmento do ensino fundamental; e, na escola pública, no primeiro segmento do ensino fundamental. No gráfico a seguir, com relação à taxa de reprovação nas escolas privadas e públicas no Brasil, em 2005, podemos ver que a situação se mantém: nas escolas privadas, as reprovações são maiores no ensino médio, já nas escolas públicas os maiores índices são no ensino fundamental.

GRÁFICO 1 - Taxa de reprovação das escolas brasileiras em 2005, segundo a dependência administrativa

TAXA DE REPROVAÇÃO

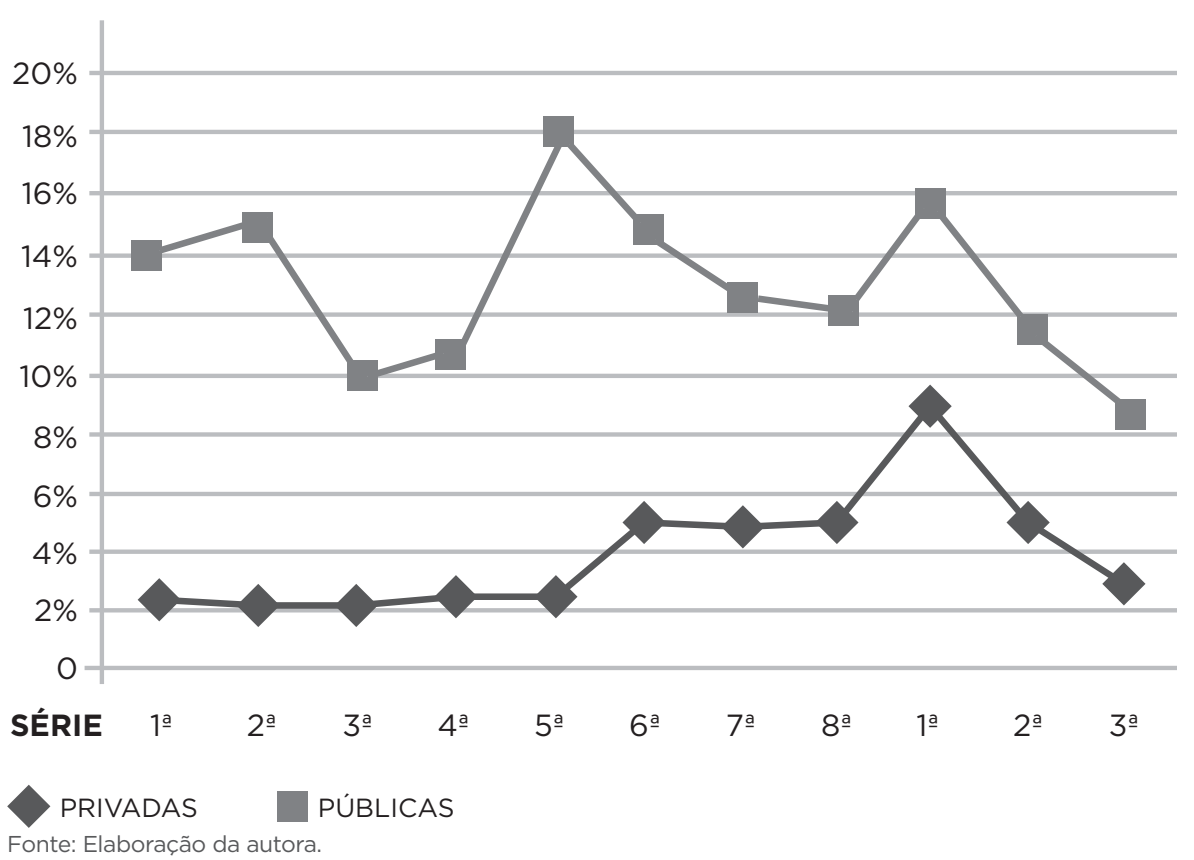

O objetivo deste artigo é aprofundar a temática para saber como acontece a reprovação naquelas escolas que são consideradas e avaliadas como as melhores do país, onde alunos e professores encontram uma estrutura pedagógico-administrativa que funciona a seu favor. Principalmente porque, como 
1 Uma escola pública federal e 14 privadas. essas instituições são privadas, a análise do seu desempenho fica adstrita aos seus resultados do Exame Nacional do Ensino Médio (Enem), pois elas não possuem Ideb.

Este trabalho foi desenvolvido no âmbito da tese de doutorado (MANDELERT, 2010) e, neste artigo, será focalizada a parte referente ao estudo de caso feito em duas escolas privadas de prestígio. Para a escolha das duas instituições, foram selecionadas as 30 escolas públicas ou privadas que tiveram os melhores resultados no Enem de 2005 e 2006, no município do Rio de Janeiro. Foram consideradas apenas as 15 escolas $^{1}$ que oferecem do ensino fundamental até o ensino médio, pois o interesse era justamente ver essas transições escolares em uma mesma instituição. Com os dados das taxas de reprovação do censo escolar de 2003 a 2005, foi possível perceber que a reprovação nas escolas privadas de prestígio, assim como na escola pública de prestígio, não é um acontecimento isolado. Além disso, a manutenção de um padrão do momento em que elas acontecem foi uma indicação de que a reprovação é um mecanismo escolar fortemente implantado no sistema educacional brasileiro. Dentre as 15 escolas, foram escolhidas duas por atenderem famílias que ocupam as melhores posições sociais, em termos de estrutura e volume de capitais (BOURDIEU, 2005).

As duas escolas do estudo de caso são confessionais e para caracterizá-las foram utilizadas as taxonomias construídas por Ballion (apud NOGUEIRA, 1998, p. 53), tendo como referência a rede de estabelecimentos particulares da região parisiense, e a de Paes de Carvalho (2004), elaborada com base nos percursos escolares dos graduandos de Engenharia Elétrica e Direito da PUC-Rio, em 2000. Essa opção foi feita, porque elas oferecem os elementos necessários para a compreensão do tipo de escola, sem possibilitar a sua identificação conforme solicitado pelas mesmas. De acordo com Ballion, seriam "estabelecimentos de excelência":

[...] estabelecimentos tradicionais, reputados pela qualidade do ensino fornecido e pelo rigor da disciplina. Seu alto nível de exigência acadêmica aparece associado a uma forte seleção na entrada, como, por exemplo, a recusa de candidatos com histórico escolar insuficiente. Sua clientela é recrutada entre os favorecidos cultural e economicamente. (apud NOGUEIRA, 1998, p. 53) 
Paes de Carvalho completa a descrição com a categoria "empreendimentos institucionais":

[...] correspondem fundamentalmente ao conjunto das esco-

las confessionais tradicionais, nas quais podemos identificar duas características particulares: todas possuem uma Congregação Religiosa como mantenedora, e a definição da missão institucional propõe uma formação integral baseada em valores humanistas e religiosos, sem perder de vista a necessidade de uma integração socialmente responsável dos alunos à sociedade. $(2004,113)$

Foi realizado um mapeamento de quando essas escolas reprovam, quantos alunos são reprovados, o que acontece com os alunos reprovados e, finalmente, como as escolas recompõem as turmas com as sucessivas reprovações que ocorrem durante uma geração escolar. A razão da mostra ser apenas de duas escolas é que esse mapeamento não poderia ser feito com os dados do censo escolar, pois estes não oferecem a acuidade necessária ao que se pretendia estudar. O censo até 2007 teve como unidade de análise a escola, e não os alunos, por isso os indicadores de fluxo escolar, assim como os de rendimento, não eram exatos. Foi necessário ir aos registros das escolas para captar esse fluxo, tendo em vista que nem as escolas privadas possuem um acompanhamento das taxas de rendimento e transição dos seus alunos.

\section{ESTUDOS SOBRE O FRACASSO ESCOLAR NAS CAMADAS MÉDIA E ALTA E ESCOLAS DE PRESTÍGIO}

Nos poucos estudos encontrados na revisão de literatura específica sobre o fracasso escolar nas classes média e alta, foram observadas variadas abordagens e modalidades explicativas. Além de ser importante salientar que cada trabalho considerou de forma diferente o que seriam esses segmentos, até porque essa definição não tem consenso na literatura.

Focalizados nos alunos de classes média e alta e/ou em suas famílias, temos os trabalhos de Fourastié (1972) e Ballion (1977), na França, e os dos brasileiros Salomon (2001) e Rodrigues (2004). Fourastié realizou, entre 1964 até 1968, sete 
2 Posição na fratria significa qual lugar que o aluno ocupa em relação aos irmãos (ex: primogênito ou caçula)

3 Nos últimos 30 anos a situação das meninas mudou bastante, conforme os estudos de Baudelot Establet, Allez les filles (1992), sobre a ascensão escolar das meninas na França e no mundo. No Brasil, as mulheres tendem a ter um desempenho educacional superior ao dos homens, conforme Alves (2007), Paes de Barros colegas (2001).

4 Segundo Ballion (1977) existem diferentes tipo de estabelecimento de rattrapage, uns são mais permissivos, outros mais autoritários, assim como para diferentes tipos de aluno: com problemas específicos, como dislexia etc., ou por idade. Como essas escolas não estão submetidas por contrato à Educação Nacional, as instituições são inteiramente responsáveis por sua organização pedagógica. Assim, podem oferecer condições pedagógicas melhores do que aquelas do ensino público francês, oferecendo aulas de apoio

5 Os dados do autor são de 1962, à época quase a metade dos alunos dos meios favorecidos não conseguia obter 0 baccalauréat (equivalente ao vestibular brasileiro) enquetes sobre a escolaridade dos filhos de politécnicos, professores e egressos da École Normale Supérieure, industriais, artistas, altos funcionários e juízes. O objetivo geral da pesquisa era conhecer os resultados escolares e universitários daqueles que por definição não teriam os obstáculos clássicos de ordem econômica e social. As taxas de escolarização encontradas por ele foram bem mais altas do que as que eram reveladas pelo censo sobre a média da população. No entanto, muitos não tinham alcançado o ensino superior ( $30 \%$, em média), ou tinham alcançado escolaridade menor do que a dos pais. Na análise, as variáveis sexo, nível escolar dos pais e lugar na fratria ${ }^{2}$ tiveram correlação estreita com a trajetória escolar. Meninas obtinham pior resultado do que os meninos, ${ }^{3}$ a maior escolaridade dos pais resultava em melhor resultado escolar, além disso, os primogênitos tinham vantagens em relação aos irmãos.

As diferenças de mentalidades, ou seja, a menor importância conferida à escolaridade dos filhos por industriais e artistas, também se configuraram como um fator que contribuiu para a menor escolaridade. Apesar disso, Fourastié concluiu que, se o contexto cultural tomado no seu sentido mais amplo é favorável, são as capacidades psicobiológicas do sujeito que têm um papel preponderante na explicação do sucesso escolar. Mesmo sem focalizar o fracasso escolar propriamente dito, o estudo desperta interesse por levantar hipóteses sobre variáveis que levam a um menor rendimento escolar por parte dos meios favorecidos.

Ballion publicou, em 1977, o livro L'argent et l'école, sobre o fracasso escolar nos meios economicamente favorecidos. Sua pesquisa foi feita com duas amostras diferentes, em dois períodos. A primeira amostra foi com 170 alunos em ano de formatura escolar, e a segunda, com 500 alunos dos denominados établissements de rattrapage, o que poderia ser traduzido como estabelecimentos de recuperação, isto é, escolas especializadas em proteger os filhos dos meios favorecidos da seleção feita pela escola pública, criando um ambiente de estudo mais adequado para eles. ${ }^{4}$

$\mathrm{O}$ autor demonstrou que o número de insucessos era bem maior do que se esperava nessas camadas sociais. ${ }^{5}$ Além disso, descobriu que "l'argent efface l'échec", ou seja, o capital econômico consegue "apagar" as trajetórias irregulares desses alunos. 
As famílias conseguem, por meio de estratégias variadas, corrigir os efeitos possivelmente perversos do fracasso escolar.

Uma das estratégias nesse sentido é a opção por escolas de rattrapage, que funcionam como uma ponte para esses alunos, pois podem facilitar sua ascensão escolar. A hipótese explicativa dada por Ballion para a trajetória acidentada desses estudantes é individualizada e de base psicológica. Os alunos de um estabelecimento de rattrapage dos quais o autor foi professor na sua experiência docente eram perfeitamente normais no que tange à inteligência, por vezes eram até acima da média. Por isso a razão do insucesso era, para ele e para os outros professores, colegas seus, um mistério.

Ao analisar a questão na pesquisa, atribuiu ao temperamento do aluno, em francês caracteriel, um traço da personalidade que diante do fracasso e de experiências negativas escolares faz com que faça um desinvestimento na escola, piorando cada vez mais a situação.

No Brasil, alguns trabalhos apontam as trajetórias irregulares nas camadas média e alta, mas não estudam o tema especificamente. ${ }^{6}$ Recorrendo ao banco de dados da Coordenação de Aperfeiçoamento de Pessoal de Nível Superior (Capes), ${ }^{7}$ encontrei a dissertação de mestrado de Rodrigues (2004), sobre a repetência nas camadas médias, com foco nas famílias.

Inicialmente, Rodrigues tentou entrevistar alunos de escolas privadas, mas não obteve êxito. Primeiramente, as coordenadoras contatadas disseram que a reprovação era muito baixa, pois era feito um acompanhamento pedagógico intenso ao longo do ano escolar, depois afirmaram que a maioria dos alunos reprovados troca de estabelecimento. A pesquisadora tentou realizar a aproximação com as famílias das escolas particulares de outras formas, mas não obteve sucesso. Optou por realizar sua pesquisa em escolas públicas com clientela reconhecidamente de camadas médias ${ }^{8}$. Conseguiu entrevistar 20 famílias que se encaixavam no perfil adotado. Verificou que tanto as escolas como as famílias explicavam a reprovação como resultado de problemas biológicos, médicos ou psicológicos, isto é, centrados no indivíduo. Portanto, tal qual Ballion (1977), seriam aspectos do aluno que explicam a reprovação.

A autora detectou "acordos" entre as escolas e as famílias para que o aluno não fosse reprovado, fazendo inclusive uma
6 Paes de Carvalho (2004), Brandão e Lelis (2003).

7 Disponivel em: <http:// www.capes.gov.br/servicos/ bancoteses.html>. Acesso em: 14 jul. 2009.

8 Rodrigues caracterizou as famílias de camadas médias pela renda familiar bruta e pela escolarização dos pais. 
9 A autora caracterizou camadas médias como famílias com renda familiar bruta de 32 a 100 salários mínimos, moradia própria e bem localizada.
10 Nomenclatura usada pela autora, no Rio de Janeiro conhecida como "pagou-passou". diferenciação entre "reprovação" e "repetência". Com a primeira, haveria o registro no histórico escolar; na segunda, a criança é aprovada na escola e é matriculada em outro estabelecimento na mesma série no ano seguinte. A autora considera que esses "acordos" podem colocar em dúvida as estatísticas oficias nas escolas particulares. A reprovação escolar enquanto experiência familiar pode ter diferentes significados para as famílias pesquisadas: "dinheiro ou tempo perdido", "aprendizado" e "sofrimento" são alguns dos mais citados.

Entre as principais conclusões do trabalho figuram a verificação de que a reprovação escolar repercute sobre o cotidiano das famílias mesmo antes de acontecer de fato e a percepção de que isso se deve, entre outras coisas, à centralidade que a escolaridade dos filhos tem de fato para essas famílias de camadas médias. Outro dado importante é que todas as famílias consideram que a reprovação é um evento que deixa uma marca muito difícil de apagar, tanto para a família quanto para o aluno.

A segunda pesquisa foi encontrada na bibliografia de Rodrigues (2004), foi a tese de doutorado de Salomon (2001).É um estudo de caso sobre dez jovens de classe média ${ }^{9}$ em situação de fracasso escolar ou de vida escolar fragmentada. A pesquisadora tentou estabelecer uma amostra em que os alunos não apresentassem nenhuma das variáveis comuns que interferem na aprendizagem. Assim, os alunos selecionados não apresentavam nenhum distúrbio específico, também não eram oriundos de famílias de pais separados na primeira infância. Este segundo critério também foi adotado porque a relação dos pais com a vida escolar dos alunos era uma dimensão importante do estudo.

Como na pesquisa de Rodrigues (2004), a autora também teve dificuldades de acesso aos alunos por meio das escolas privadas. Muitas disseram não viver a situação de fracasso escolar, pois ofereciam um atendimento individualizado às necessidades dos alunos, realizando um trabalho conjunto escola-família. Outras alegaram problemas éticos para não indicar nomes de alunos nessa situação. Duas escolas foram claras no seu receio em participar da pesquisa por problemas de imagem. Mesmo nas escolas "pagar-passar", ${ }^{10}$ ela não obteve uma resposta rápida. Após uma longa espera, ela conseguiu compor sua amostra com famílias de alunos que a procuraram por indicação de algumas das coordenadoras previamente contatadas, 
e por uma escola que atualmente é reconhecida como uma instituição do tipo "pagar-passar".

Tendo por base o estudo de Lahire (1997), seu objetivo era compreender as formas como a família pode condicionar a situação de fracasso escolar e como os alunos e suas famílias percebem as formas de participação da escola nesse processo de exclusão ou de "construção" de uma situação considerada como fracasso escolar, isto é, buscava um modelo de configurações familiares que levasse ao fracasso.

A autora concluiu que essas famílias possuem uma postura caracterizada pela valorização do consumo e do lazer, em detrimento da produção, do trabalho e do estudo, ou seja, de valores ligados à cultura escolar. Os alunos, por sua vez, apresentaram uma relação socioafetiva essencialmente negativa com a aprendizagem. Os estudantes questionam os professores e até mesmo os responsabilizam pelos seus resultados. A autora ainda salienta que os alunos demonstraram uma alienação com relação à escola, o desinteresse pela aula, a falta de autoridade do professor, o desrespeito, o autoritarismo, a intransigência, além de processos de seleção e discriminação por parte da escola. Com o recorte da pesquisa, não é possível compreender se os alunos têm essa postura por terem sido reprovados, ou se esse comportamento já era anterior ao evento. De acordo com Ballion (1977), podemos pensar que as atitudes descritas também são uma consequência da reprovação e não apenas a geradora do evento.

O estudo de Nogueira (2004), apesar de não ter o foco em trajetórias escolares irregulares nos meios favorecidos, apresenta interesse nessa revisão da literatura. A autora pesquisou em Minas Gerais 25 famílias de grandes empresários. Teve que incluir na amostra, por dificuldades de acesso, médios empresários também. O objetivo era conhecer as trajetórias escolares dos jovens e as estratégias educativas postas em prática pelos pais desses jovens ao longo de suas trajetórias. Ela verificou que mais da metade dos jovens pesquisados tinham sofrido alguma reprovação ao longo de sua escolarização. Nas conclusões, a autora considera que esses itinerários irregulares devem ser fruto do tipo de relação que essas famílias estabelecem com a escola de investimento moderado. ${ }^{11}$ Coloca, portanto, a explicação da reprovação mais uma vez dentro do corte de classe. Como esses alunos "não precisam" da escola, pois já têm nas

\footnotetext{
11 Para os jovens, a percepção geral é de que a escola era "pouco", em sentido múltiplo. Era uma pequena porção do seu cotidiano, não constava entre suas preferências pessoais e afetivas e, por fim, porque a escola representa um papel secundário em sua preparação profissional. Já em relação às estratégias familiares, a autora considerou que essas famílias não "apostam todas as suas fichas na escola".
} 
empresas da família uma perspectiva de futuro, não há razão para investir nos estudos. Como o foco da autora é nas famílias e não na escola, não há um estranhamento quanto ao número de reprovações.

Tendo por foco a reprovação de alunos de instituições de prestígio, foi encontrada apenas uma dissertação de mestrado. Galvão (2003) analisou, com base nos estudos de Bourdieu, a experiência de democratização do acesso ao Colégio Pedro II - escola pública federal do Rio de Janeiro, quando esta passou a ter o acesso à classe de alfabetização por sorteio e não por uma prova de conhecimentos - como ocorre no $6^{\circ}$ e no $1^{\circ}$ ano do ensino médio.

Para realizar essa tarefa, a autora realizou a análise de meios, modos e condições em que os alunos foram excluídos. Assim, estudou as jubilações que ocorreram ao longo de 18 anos de existência de uma das unidades do Colégio Pedro II, o percurso escolar de 178 crianças que ingressaram no colégio por sorteio e, finalmente, tentou estabelecer uma correlação entre a origem social dos alunos e seu desempenho escolar.

Desse grupo, apenas 48 alunos (27\%) conseguiram completar sua trajetória escolar sem nenhuma reprovação, sendo que 58 alunos saíram da escola por pedidos de transferência ou jubilações. Ela constatou que os alunos que concluíram o $3^{\circ}$ ano do ensino médio eram oriundos na sua maior parte das classes favorecidas, ao contrário dos que entraram na classe de alfabetização que eram de classes desfavorecidas, por conta de características socioeconômicas. Concluiu que, apesar de o acesso para as classes de alfabetização ser por sorteio, a origem social continuou tendo uma forte associação com o desempenho escolar no período pesquisado (1990/2002).

É possível verificar que, nas pesquisas de Rodrigues (2004) e Salomon (2001), o objetivo não é explicar as causas escolares da reprovação ou seus efeitos, e sim investigar o fenômeno como um evento familiar. A pesquisa de Nogueira (2004), apesar não estudar o fenômeno em si, também o estuda na esfera familiar. A pesquisa de Galvão está inserida nas pesquisas que analisam a escola sob uma perspectiva reprodutivista, em outras palavras, como a escola traduziria, por meio de mecanismos internos, as hierarquias sociais. Nenhum dos estudos encontrados, no entanto, pesquisou a magnitude do fenômeno. 


\section{DADOS E TRATAMENTO}

Para realizar esta análise, foi considerado, de forma longitudinal, o movimento de alunos em um percurso ideal dos 11 anos ( $1^{\text {a }}$ série do ensino fundamental ${ }^{12}$ até o $3^{\circ}$ ano do ensino médio) necessários para a conclusão da educação básica nas duas escolas. Este estudo permitiu analisar o impacto das reprovações e dos abandonos dos alunos nas estratégias de composição das turmas pelas escolas. Em outras palavras, foi possível verificar como estava composta a $1^{\text {a }}$ série do ensino fundamental em 1995 e as subsequentes, até a formatura no $3^{\circ}$ ano do ensino médio em 2005, computando o número de alunos promovidos, repetentes e o número de alunos novos. ${ }^{13}$ Portanto, foram observados os 11 anos necessários para a formatura de uma turma, na verdade de quatro, pois foi feito o mesmo levantamento para os anos de 1995, 1996, 1997 e 1998, até a provável formatura em 2005, 2006, 2007 e 2008, respectivamente.

Os indicadores de fluxo do censo escolar, promoção, evasão e repetência não oferecem essas informações. O que é possível com esses dados é a análise da progressão dos alunos de um ano $t$ para o outro (ano $t+1)$, em determinado nível do ensino seriado, em relação à sua condição de promovido, repetente ou evadido. Logo, não temos informações sobre os novos ingressantes na escola. Os indicadores de rendimento também não, pois só avaliam a situação do aluno no mesmo ano.

Para realizar a análise, foi construído um banco com os dados das escolas A1 e A2, conforme foram denominadas as escolas selecionadas, sendo a turma de 2005 e a turma de 2006, e assim por diante. Também foi considerado cada percurso ideal de 11 anos um grupo diferente. Não foram denominados de coorte, nesta parte da análise, porque não houve o acompanhamento da trajetória dos alunos, e sim a composição das turmas na sucessão das séries. A base de dados foi construída colocando o nome do aluno, a matrícula, o ano de entrada na escola e, depois, série por série, as informações sobre sua turma, aprovação, reprovação ou abandono. Nas séries em que o aluno não estava matriculado na escola, foi considerado dado faltante. Foi necessário retornar às escolas diversas vezes para validar dados, tendo em vista a incongruência dos mesmos. Por exemplo, alunos que constavam como reprovados tinham sido afinal aprovados, de outros não constava o abandono no registro e assim por diante.
12 Utilizou-se a denominação de $1^{a}$ série, e não de $2^{\circ}$ ano do ensino fundamental, porque era a vigente à época e seria um anacronismo fazer de outro modo.

13 De acordo com o glossário de termos, variáveis e indicadores educacionais do Sistema de Estatísticas Educacionais (Edudatabrasil) <http://www.edudatabrasil. inep.gov.br/glossario.html>, existem as taxas de transição: promoção, evasão e

repetência, bem como as taxas de rendimento: aprovação, reprovação e abandono. A taxa de repetência consiste da proporção de alunos da matrícula total na série $\mathrm{k}$, no ano $t$, que se matriculam na série $k$, no ano $t+1$. A taxa de reprovação é a proporção de alunos da matrícula total na série k, no ano t, que são reprovados. Portanto, foram observados os dois tipos de indicadores. 
14 De acordo com a informação veiculada na imprensa (ALMEIDA, 2009).

15 São denominados de alunos novos aqueles que estão ingressando naquele ano na escola, e alunos antigos aqueles que estão há mais de um ano na instituição.

16 Com exceção dos formandos de $2008 \mathrm{da}$ Escola A2, que foram em maior número do que os matriculados na primeira série de 1998, 122 e 104 respectivamente.
Além disso, foi desenvolvida uma estratégia que viabilizasse a análise da coorte de uma das turmas da Escola A1: foram verificados os nomes dos alunos que entraram na primeira série, série de entrada nas escolas, até os que conseguiram se formar no ensino médio, onze anos depois. Na análise exploratória da coorte de turma, foi feita uma tentativa de estabelecer o perfil do aluno que permanece nesse tipo de instituição, com os dados de ocupação de pai e mãe, o endereço e desempenho acadêmico.

\section{RECRUTAMENTOS DE ALUNOS}

Nas duas escolas, a seleção já é demonstrada por uma realidade de quatro candidatos por vaga no primeiro ano do ensino médio. ${ }^{14}$ Para o $1^{\circ}$ ano do ensino fundamental, por exemplo, a informação dada pela supervisora da Escola A1 é que foram 148 candidatos para 75 vagas no em 2010.

A primeira questão de interesse era saber quantos alunos estavam matriculados nas séries ao longo dos anos. Como poderemos ver nos gráficos 2 e 3, o recrutamento de alunos novos para a primeira série variou no tempo nas duas escolas. A primeira série da Escola A1 teve 78 alunos em 1996 e 1997, mas teve 90 em 1998; já na Escola A2, em 1995, entraram na $1^{\text {a }}$ série 127 alunos, mas, em 1998, entraram apenas 104 alunos novos. ${ }^{15} \mathrm{O}$ número máximo de alunos em todos os anos é na $5^{a}$ série, pois há uma entrada grande de alunos novos, provavelmente provenientes de escolas que só vão até a $4^{\mathrm{a}}$ série. Ou, como denominou Paes de Carvalho (2006), como resultado de um "refinamento" do investimento escolar: essa grande quantidade de trocas de escola que se observa entre o final do primeiro segmento do ensino fundamental e o início do segundo.

Nas duas escolas, o menor número de alunos é sempre no $3^{\circ}$ ano do ensino médio. ${ }^{16}$ Conforme se verá, apesar de não haver um número fixo de matrículas ao longo das séries, podemos ver que existe um fluxo mais ou menos regular de alunos, isto é, as escolas mantêm a mesma ordem de grandeza em cada série. A diferença é que na Escola A1 a curva descendente é mais acentuada do que na Escola A2, pois nesta o número de alunos nas séries é mais próximo.

Outro dado interessante de se ressaltar é que, na Escola A1, a turma 2008, apesar de ter havido uma entrada muito grande de alunos a partir da $3^{\mathrm{a}}$ série (coluna cinza-escuro do 
gráfico), chegando a ter na $7^{\mathrm{a}}$ série quase 40 alunos a mais do que nas outras turmas, ${ }^{17} \mathrm{o}$ número de formandos não acompanhou a proporção, e a diferença entre o menor número de formandos, que foi a turma de 1995/2005, caiu para 17 alunos, o que pode parecer um ajuste para um número desejável de alunos no $3^{\circ}$ ano do ensino médio.

GRÁFICO 2 - Número de alunos, por série, nas quatro turmas da Escola A1

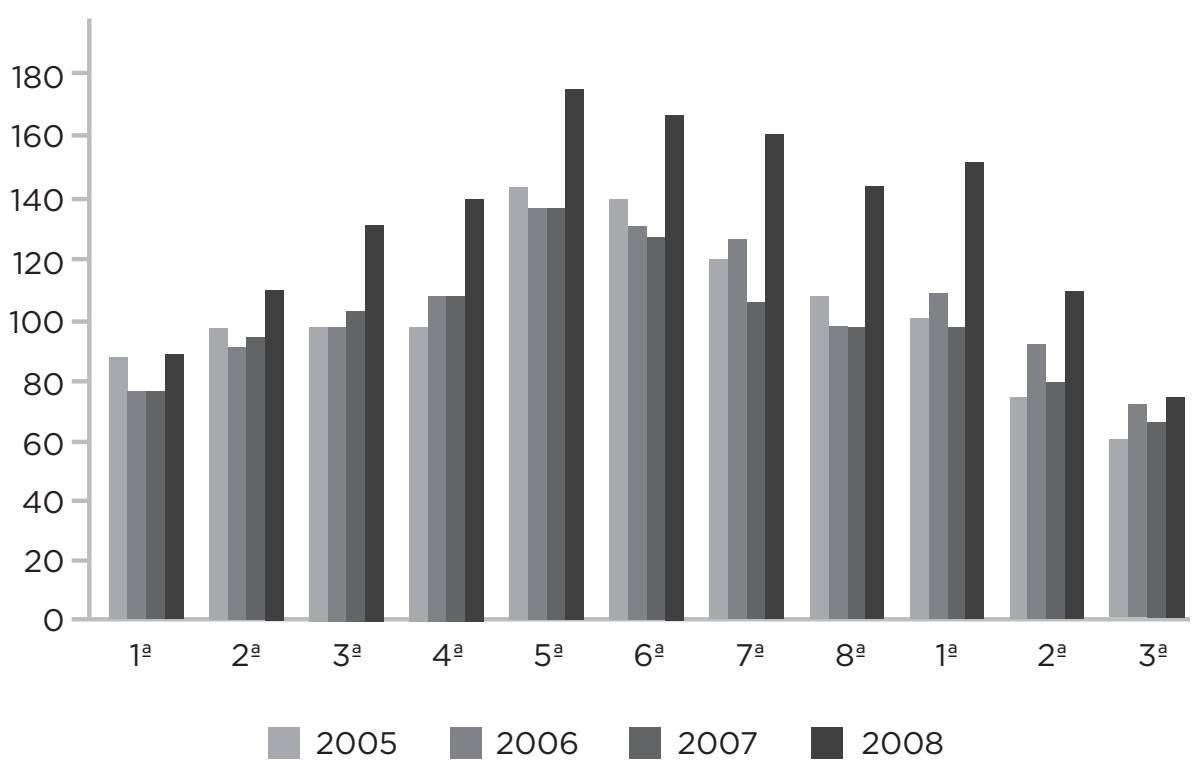

Fonte: Elaboração da autora.

GRÁFICO 3 - Número de alunos, por série, nas quatro turmas da Escola A2

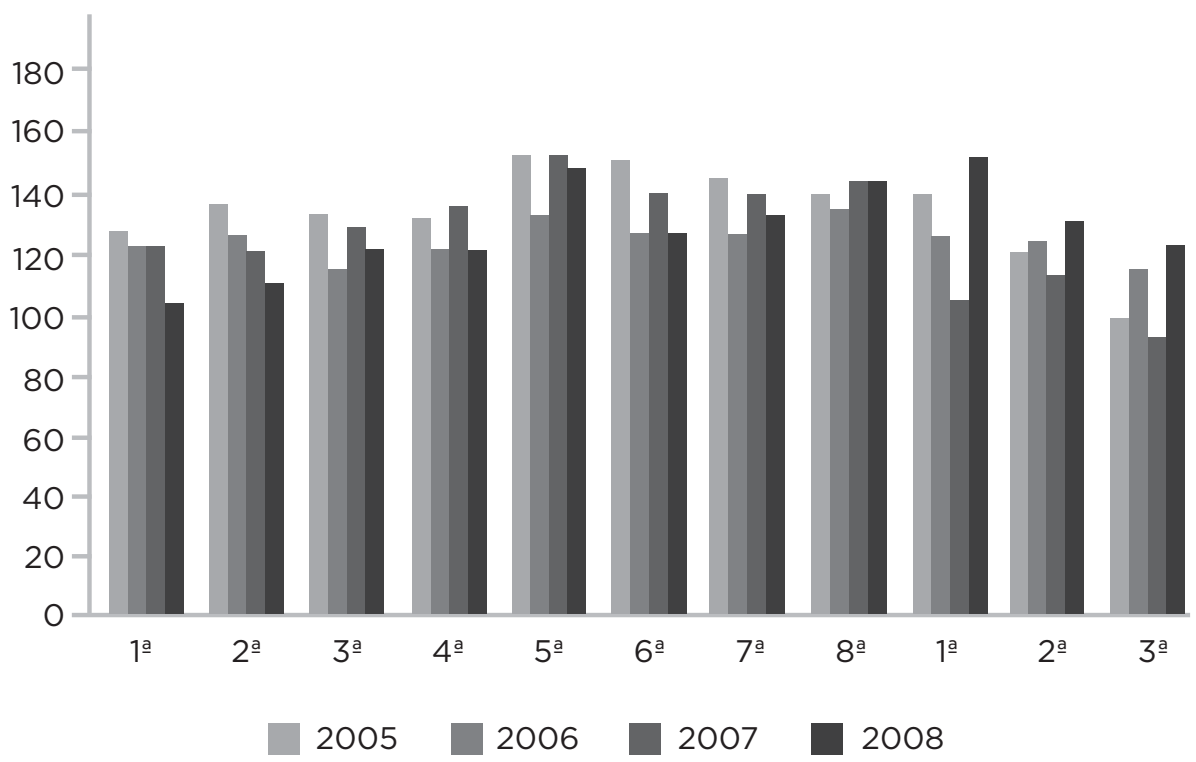

Fonte: Elaboração da autora. 


\section{FLUXO DOS ALUNOS}

Para compreender melhor essa flutuação de número de alunos, apresenta-se o que foi chamado de consolidado das quatro turmas com a composição das séries das duas escolas. Somaram-se os dados das quatro turmas em cada escola, formando uma coluna para cada série. Desse modo, obteve-se a coluna da primeira série agregando-se os dados das primeiras séries de 1995, 1996, 1997 e 1998, e assim nas séries subsequentes. No gráfico, foi colocada em cada série a proporção de alunos novos, alunos promovidos, repetentes e repetentes em anos anteriores. A ideia era entender como era a composição das séries.

Podemos ver nos gráficos 4 e 5 que, na primeira série, não há repetentes, apenas alunos novos. Depois da primeira série, o maior número de alunos novos é na $5^{\mathrm{a}}$, com quase $30 \%$ do total na Escola A1 e pouco menos de $20 \%$ na Escola A2. A Escola A2 aceita, em proporções variadas, novos alunos em todas as séries, já a Escola A1 não admitiu alunos novos na $6^{\mathrm{a}}$ nem na $7^{\mathrm{a}}$, pois, como vimos anteriormente, houve uma entrada maior de alunos na $5^{\mathrm{a}}$ série. Nas duas escolas, vemos que, no $1^{\circ}$ ano do ensino médio, há um aumento de matrículas novas (em torno de $10 \%$ em ambas).

Embora o número de reprovados seja pequeno no primeiro segmento do fundamental, como se verá adiante, é possível também observar nos gráficos 4 e 5 que uma boa proporção dos alunos reprovados do primeiro segmento do fundamental praticamente não permanece nas escolas. Isso corrobora o achado de Rodrigues (2004) que, em escolas de prestígio em Belo Horizonte, não conseguiu reunir famílias com alunos repetentes desse segmento para fazer parte de sua mostra. A autora foi informada de que são poucos os alunos que reprovam e os que são, em geral, pedem transferência para outras escolas. De fato, o número de alunos que é reprovado no $1^{\circ}$ segmento do ensino fundamental é muito pequeno, como se verá nas tabelas 1 e 2 . 
GRÁFICO 4 - Composição das séries da Escola A1 de acordo com o status dos alunos no fluxo escolar (os dados das quatro turmas avaliadas foram consolidados)

\section{PORCENTAGEM DE ALUNOS}

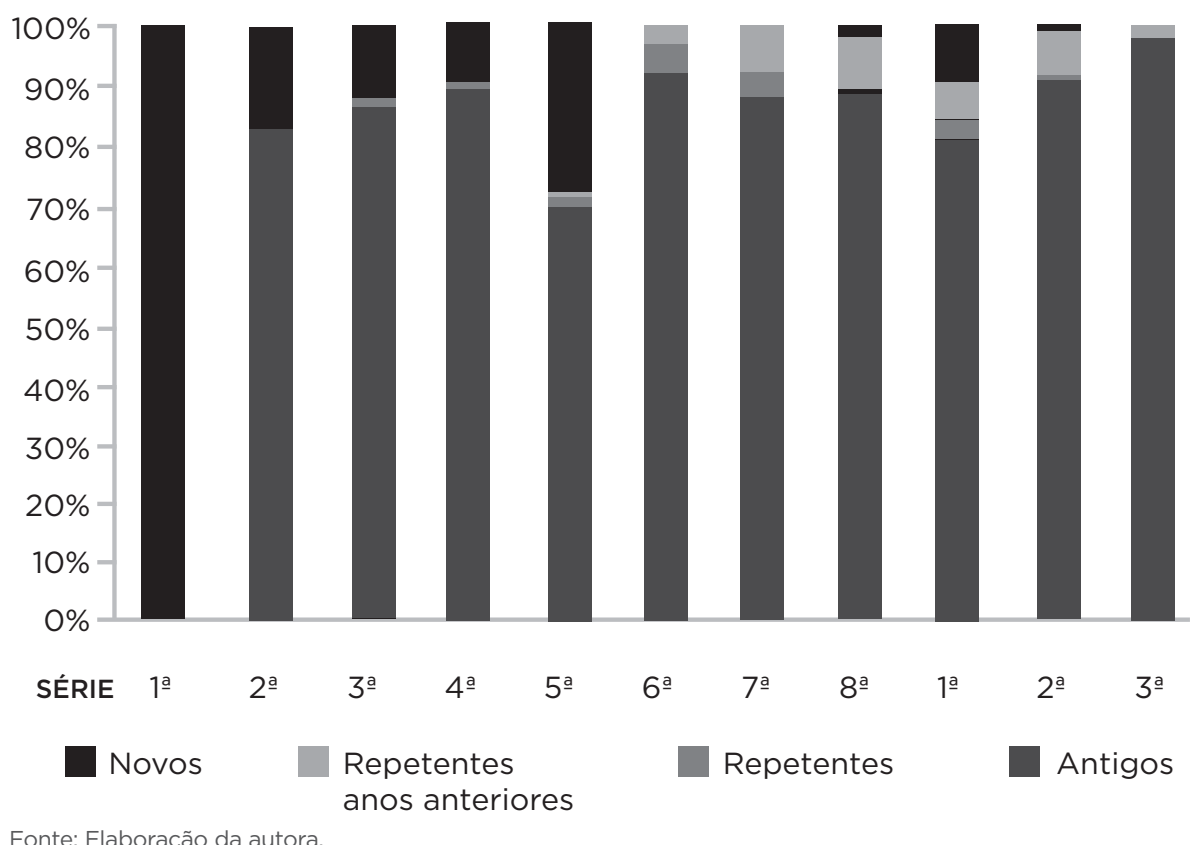

Fonte: Elaboração da autora.

GRÁFICO 5 - Composição das séries da Escola A2 de acordo com o status dos alunos no fluxo escolar (os dados das quatro turmas avaliadas foram consolidados)

PORCENTAGEM DE ALUNOS

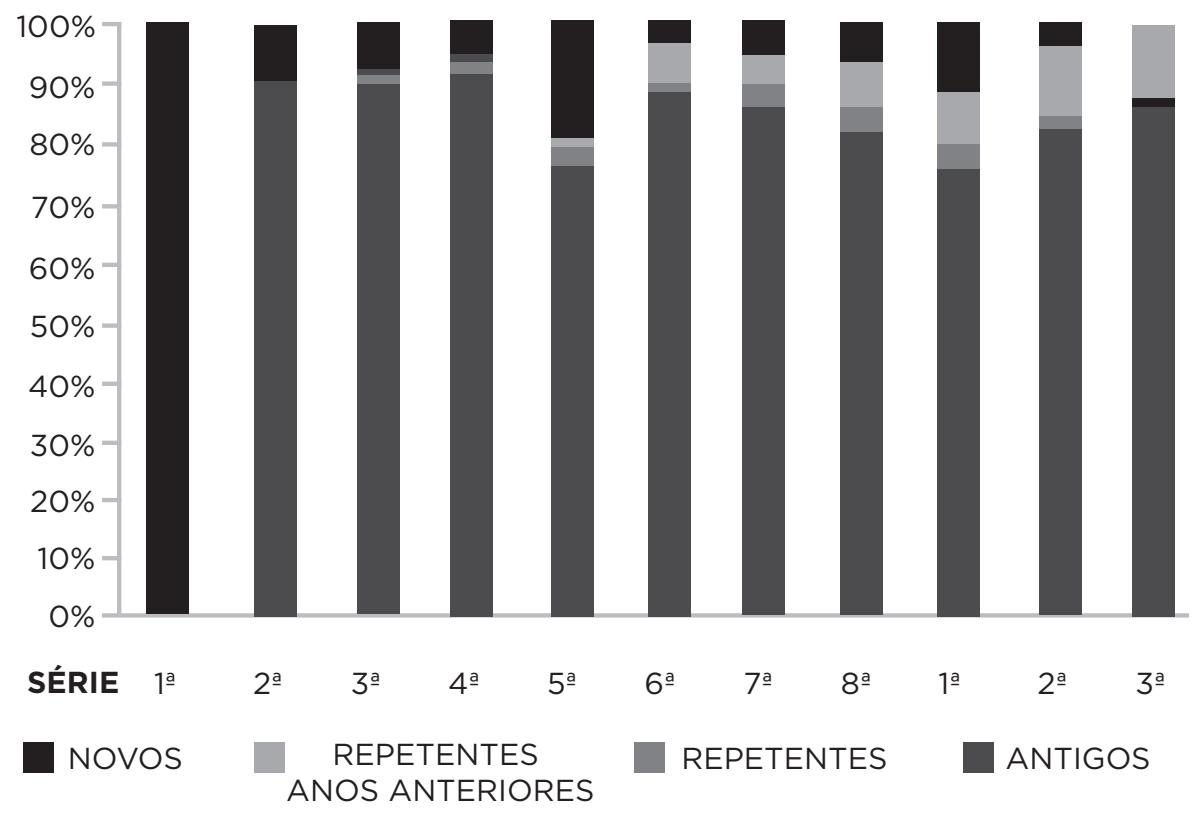

Fonte: Elaboração da autora. 
18 A exceção foi a 6a série de 2007 da Escola A1, que reprovou mais do que o ensino médio.
Nas tabelas 1 e 2, estão as porcentagens de alunos reprovados por série de todas as turmas. Podemos ver que no primeiro segmento do ensino fundamental quase não há reprovações, exceção feita à $4^{\mathrm{a}}$ série da Escola 2. Nessas escolas, a primeira e a segunda série não reprovam quase nenhum aluno em todas as quatro turmas estudadas. Nas escolas públicas é diferente, de acordo com os dados do Inep de 2005, a taxa de reprovação da $1^{\mathrm{a}}$ e da $2^{\mathrm{a}}$ série do ensino fundamental nas escolas públicas do município do Rio de Janeiro, em 2005, foi de $10 \%$ e $20,6 \%$, respectivamente. Nas escolas investigadas, o número aumenta um pouco na $3^{\mathrm{a}}$ e na $4^{\mathrm{a}}$ série, mas, em comparação com os outros anos, é muito pequeno. A situação, no entanto, muda bastante a partir do segundo segmento do ensino fundamental, aí a reprovação acontece em maior número e atinge seu ápice no $1^{\circ}$ e $2^{\circ}$ ano do ensino médio. ${ }^{18}$

TABELA 1 - Taxa de reprovação (em \%) das quatro turmas da Escola A1

\begin{tabular}{|c|c|c|c|c|c|c|c|c|c|c|c|}
\hline \multicolumn{12}{|c|}{ SÉRIE } \\
\hline Turma & $1 \underline{a}$ & $2^{a}$ & $3 a$ & $4^{a}$ & $5^{a}$ & $6^{a}$ & 7aㅗ & $8^{a}$ & 10 & $2^{\circ}$ & 30 \\
\hline 2005 & 0,0 & 0,0 & 3,0 & 0,0 & 6,5 & 10,4 & 6,7 & 2,8 & 20,4 & 20,5 & 3,4 \\
\hline 2006 & 0,0 & 0,0 & 0,0 & 1,9 & 2,9 & 5,2 & 14,4 & 3,1 & 15,0 & 11,0 & 0,0 \\
\hline 2007 & 0,0 & 0,0 & 2,0 & 2,9 & 3,6 & 17,3 & 5,6 & 2,0 & 16,2 & 10,0 & 0,0 \\
\hline 2008 & 0,0 & 0,0 & 0,8 & 0,7 & 5,8 & 3,0 & 8,0 & 2,7 & 17,9 & 16,3 & 0,0 \\
\hline Média & 0,0 & 0,0 & 1,4 & 1,3 & 4,8 & 8,5 & 8,8 & 2,7 & 17,4 & 14,4 & 0,7 \\
\hline
\end{tabular}

Fonte: Elaboração da autora.

TABELA 2 - Taxa de reprovação (em \%) das quatro turmas da Escola A2

\begin{tabular}{|c|c|c|c|c|c|c|c|c|c|c|c|}
\hline \multicolumn{12}{|c|}{ SÉRIE } \\
\hline Turma & $1^{\underline{a}}$ & $2^{a}$ & $3^{a}$ & $4^{a}$ & $5^{\underline{a}}$ & $6^{a}$ & 7 ạ & $8^{a}$ & $1^{\circ}$ & $2^{\circ}$ & $3 \circ$ \\
\hline 2005 & 0,0 & 0,0 & 0,0 & 2,3 & 10,7 & 3,5 & 6,7 & 2,8 & 20,4 & 20,5 & 3,4 \\
\hline 2006 & 0,8 & 0,8 & 1,7 & 4,2 & 5,9 & 4,8 & 14,4 & 3,1 & 15,0 & 11,0 & 0,0 \\
\hline 2007 & 0,0 & 1,7 & 0,8 & 6,7 & 11,3 & 3,6 & 5,6 & 2,0 & 16,2 & 10,0 & 0,0 \\
\hline 2008 & 1,0 & 0,9 & 0,0 & 5,0 & 5,6 & 6,3 & 8,0 & 2,7 & 17,9 & 16,3 & 0,0 \\
\hline Média & 0,4 & 0,8 & 0,6 & 4,6 & 8,5 & 1,5 & 8,8 & 2,7 & 17,4 & 14,4 & 0,7 \\
\hline
\end{tabular}

Fonte: Elaboração da autora.

Observando os dados do Inep sobre as escolas privadas do Rio de Janeiro de 2005, nota-se que as taxas de reprovação do $1^{\circ}$ ano do ensino médio dessas duas escolas são mais altas, com 
$17,4 \%$ e $13,5 \%$, quando a média das escolas particulares é de $12 \%$. Com essas informações, é possível pensar que a reprovação nessas escolas seja um sinônimo de seletividade. Não é fácil entrar nem passar por elas.

No gráfico 6, agregaram-se os dados de todas as turmas, formando um outro tipo de consolidado por escola, por conta de os valores serem muito próximos e a leitura ficar mais fácil dessa maneira. Nele não foi utilizada a nomenclatura do Inep de evasão ou abandono, pois não traduz o que ocorre com esses alunos, ou seja, estes nem evadem do sistema de ensino, nem abandonam a escola, sem ir para outra. O que acontece são pedidos de transferência para outras instituições ou no meio do ano, ou ao final. Poderemos ver a proporção e o número total de alunos das turmas de:

a. Concluintes do $3^{\circ}$ ano do ensino médio;

b. Transferidos no mesmo ano da reprovação;

c. Reprovados e que permaneceram na escola para refazer a série;

d. Transferidos.

GRÁFICO 6 - Dados consolidados das quatro turmas, para as escolas avaliadas, categorizados de acordo com a situação do aluno após os 11 anos de escolarização considerados

PORCENTAGEM DE ALUNOS

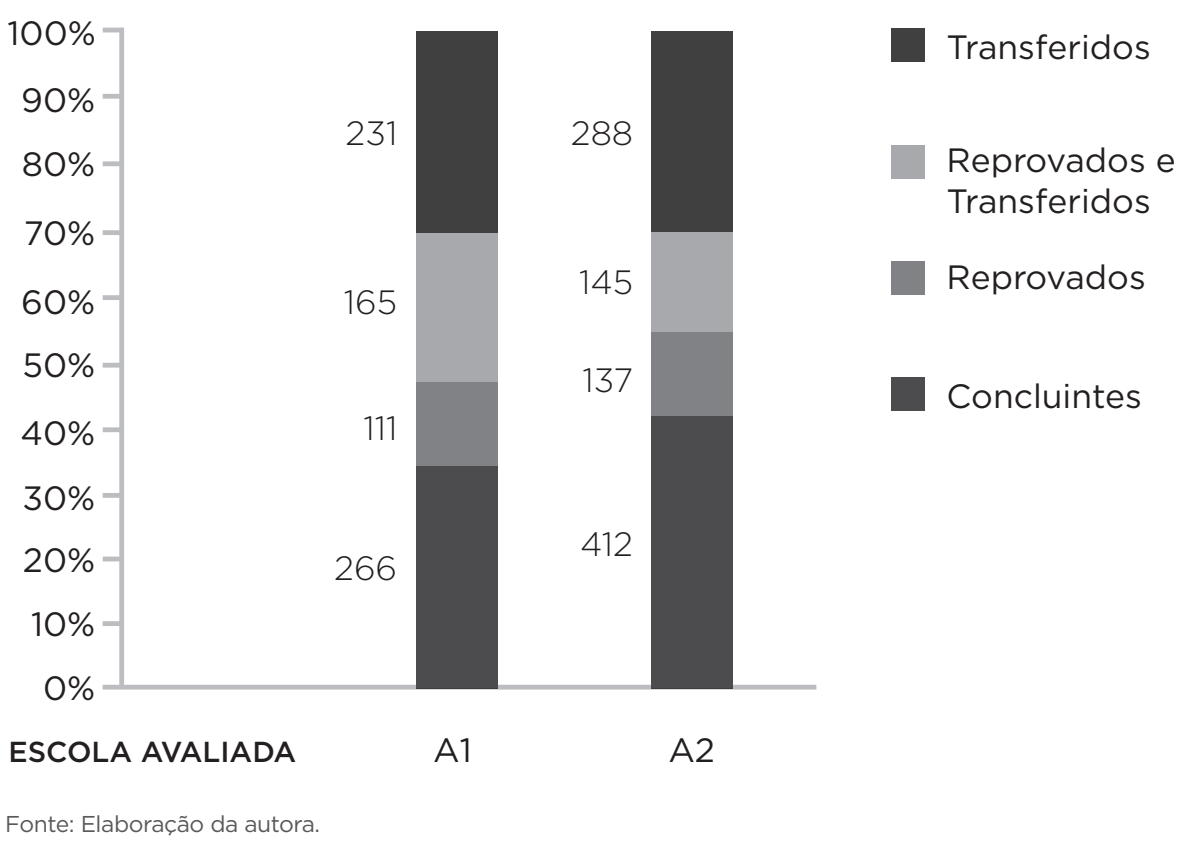


Vemos que muitos alunos entraram e saíram ao longo dos anos para o grupo que se forma no $3^{\circ}$ ano do ensino médio, os concluintes. Na Escola A1, são concluintes apenas 34\% dos alunos matriculados ao longo dos 11 anos de cada turma; na Escola A2, a porcentagem é maior, com $42 \%$. O número de alunos reprovados na Escola A1 é maior do que na Escola A2, pois, somando-se os reprovados e os que pediram transferência com aqueles que ficaram na escola, temos 36\% na Escola A1 e 29\% na Escola A2.

Outro dado importante é que os alunos da Escola A2 tendem a permanecer mais na escola do que os da Escola A1, quando são reprovados. O número de transferidos é praticamente o mesmo nas duas escolas: na Escola A1, com 30\%, e na Escola A2, com $29 \%$.

Nos gráficos 7 e 8, vemos a comparação entre as médias das reprovações e as transferências em cada escola, nas quatro turmas. No gráfico 6 da Escola A1, a curva das transferências é muito semelhante à das reprovações. Uma das coordenadoras disse que a escola costuma encaminhar alguns alunos para outras instituições por considerar que não tenham o perfil necessário e serão mais felizes em outro estabelecimento. Quando foi comentado esse dado com uma das orientadoras educacionais da Escola A1, ela disse que muito poucos saem por outra razão que não a reprovação. A escolha e a adesão ao estabelecimento são muito fortes, pois não é uma escola de bairro, quem faz a escolha pela instituição só pede transferência quando é reprovado. As transferências, assim como as reprovações, são baixas nas três primeiras séries, na $4^{\mathrm{a}}$, se elevam um pouco para atingir $15 \%$ na $6^{\mathrm{a}}$ série, quando voltam a diminuir, até atingir o ápice no $1^{\circ}$ ano do ensino médio, quando também há a maior média de reprovações.

Uma indicação de que as transferências estão ligadas de alguma forma às reprovações é que aquelas não acontecem igualmente em todas as séries. Como vimos no gráfico 6 , muitas vezes elas acontecem no mesmo ano em que o aluno é reprovado, assim sua maior incidência geralmente é nas séries de maior reprovação. Em alguns anos, elas são tão numerosas que o equivalente a uma turma de 25 a 30 alunos pede transferência.

O gráfico 8 da Escola A2 mostra um padrão diferente de transferências, o movimento é distinto: as duas curvas da Escola A2 não mantêm um padrão de quase paralelismo como no caso da Escola A1. Até porque, como veremos no gráfico 9, 
os reprovados da Escola A2 tendem a permanecer na escola, ao contrário dos reprovados da Escola A1, que pedem transferência logo na primeira reprovação. Os picos de transferências são nas mudanças de segmento. Apesar da pouca reprovação no primeiro segmento do ensino fundamental, a média de transferência na Escola A2 foi alta: nas três primeiras séries, em torno de 7\%, até chegar a $14 \%$ na $4^{\text {a }}$, o que pode ser uma indicação de que, apesar das poucas reprovações, as dificuldades encontradas pelos alunos podem ser catalisadoras da decisão de mudar de escola. Podemos pensar que essas famílias se antecipam, ou trata-se do "refinamento" do investimento escolar, conforme Paes de Carvalho (2006).

As transferências diminuem na $5^{\mathrm{a}}, 6^{\mathrm{a}}$ e $7^{\mathrm{a}}$, para voltarem a aumentar na $8^{\mathrm{a}}$ série. Já as reprovações aumentam na $5^{\mathrm{a}}$, diminuindo em seguida, para voltar a aumentar no $1^{\circ}$ ano do ensino médio, como na Escola A1. O alto índice de transferência na $8^{\mathrm{a}}$ série talvez seja uma indicação de que os próprios alunos queiram tentar novos horizontes em outras escolas, pois é nesse momento em que o aluno adquire mais autonomia em relação aos pais e pode fazer escolhas. Outra possibilidade é que no $1^{\circ}$ ano do ensino médio a pressão pelo vestibular começa, e alguns optam por fazer os últimos anos de escolarização em estabelecimentos do tipo "cursinho", preparatórios para o vestibular, ainda que a Escola A2 tenha ótimo desempenho no Enem.

GRÁFICO 7 - Número médio de transferências e reprovações, por série, considerando-se as quatro turmas da Escola A1

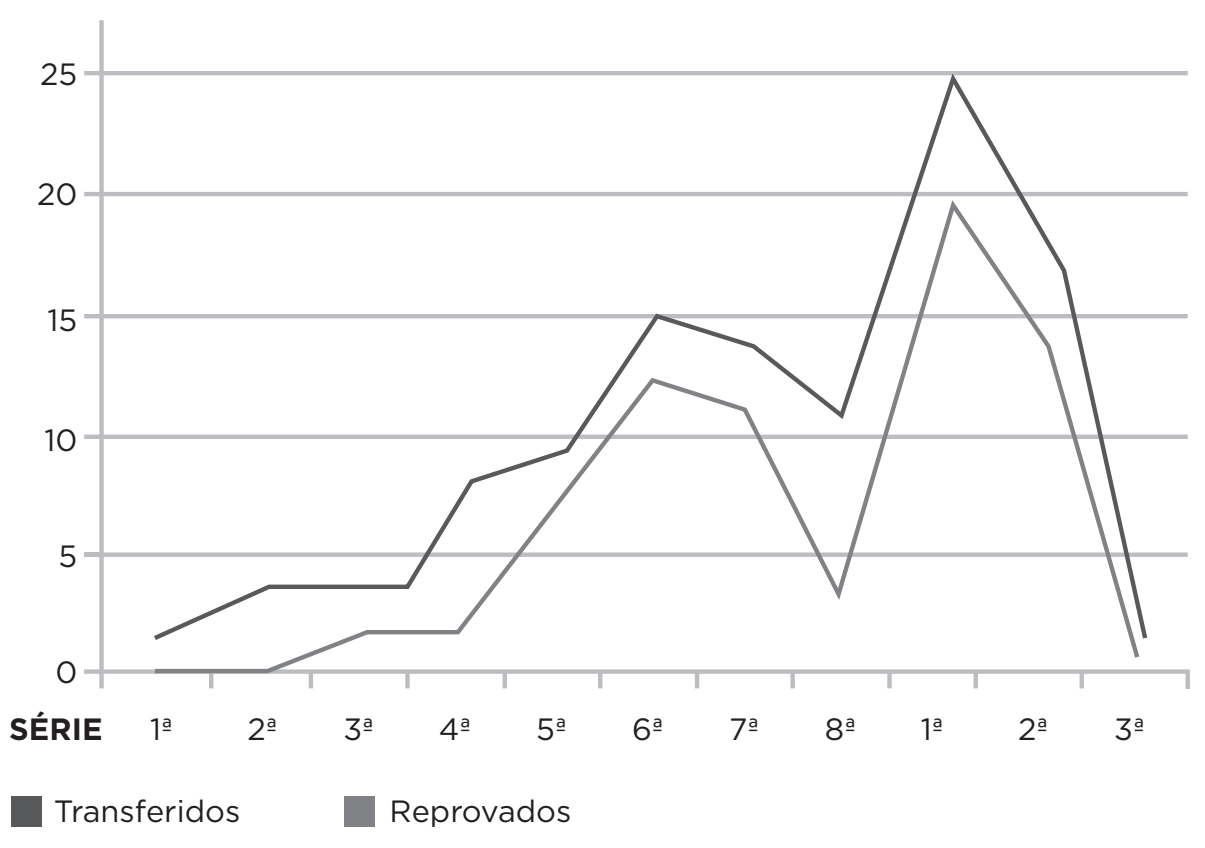

Fonte: Elaboração da autora. 
GRÁFICO 8 - Número médio de transferências e reprovações, por série, considerando-se as quatro turmas da Escola A2

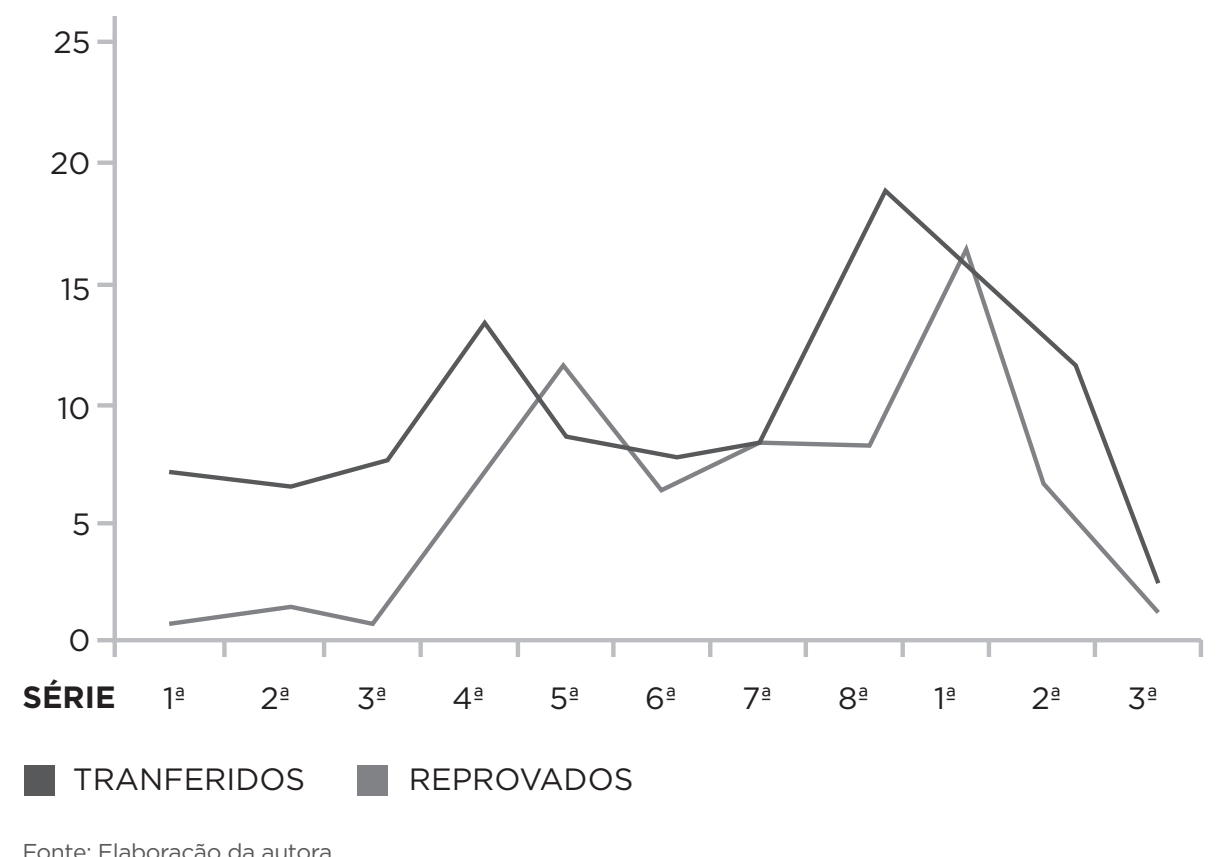

No gráfico 9, conforme a listagem nominal dos alunos levantada na escola, foi possível observar o destino dos alunos reprovados, se eles se formaram na escola ou se pediram transferência. Foi possível acompanhar apenas os alunos que foram reprovados e permaneceram nas escolas nas turmas de 1995, 1996 e 1997, pois seus nomes reaparecem na turma seguinte. Só não foi possível no de 1998, tendo em vista que não tenho os dados de 1999. Os dados parecem se direcionar de acordo com a literatura disponível sobre o tema (CRAHAY, 1996, 2006; JIMERSON, 2001; BROPHY, 2006), na qual se observa que a repetência não é uma boa estratégia para melhorar o desempenho do aluno: são poucos aqueles que conseguem se formar na escola, após a reprovação.

Na Escola A1, apenas 8,5\% (17 alunos) conseguiram se formar a despeito de terem sido reprovados uma vez. Desses formandos, nenhum é do primeiro segmento do ensino fundamental. Na Escola A2, os repetentes têm mais chance de se formar, e vemos que $18 \%$ (40) terminam sua trajetória na mesma escola, sendo que desses apenas um foi da $3^{\mathrm{a}}$ série do ensino fundamental.

Os dados das duas escolas corroboram, portanto, que o tratamento da reprovação não tem um resultado muito positivo. Mais do que recuperar o aluno, o que ocorre é a mudança de escola, pois $64,5 \%$ dos alunos reprovados na Escola A1 pediram transferência no mesmo ano e, na Escola A2, foram 55\%. 
Esse fato também ocorre na escola pública, como foi demonstrado por Costa Ribeiro (1991). As escolas particulares não costumam estimular a permanência dos estudantes que foram reprovados nas últimas quatro séries do $1^{\circ}$ grau, conforme depoimento da coordenadora da Escola A1, além do estudo de Mello e Souza; Valle Silva (1994), talvez seja esse um dos motivos pelos quais tantos alunos reprovados pedem transferência. Dos alunos que são reprovados e permanecem nas escolas, 12,5\% da Escola A1 e 15\% da Escola A2 são reprovados mais uma vez e pedem transferência na segunda reprovação. $O$ pedido de transferência sem ser atrelado à reprovação ocorre com 13,5\% dos alunos da Escola A1 e 7\% dos alunos da Escola A2. É necessário dizer que desses que pediram a transferência, a metade dos pedidos foi feita no meio do segundo semestre, o que reforça a tese, já mencionada anteriormente, de a transferência ser uma estratégia de não reprovação. Dos alunos que pediram a transferência no final do ano letivo, não foi obtido o resultado do seu desempenho para saber se porventura notas ruins teriam influenciado na sua decisão. Dos 12 alunos que reprovaram uma terceira vez, só havia a informação sobre três: um se formou, um foi reprovado de novo e pediu transferência, e o outro apenas pediu transferência.

GRÁFICO 9 - Dados consolidados dos alunos que foram reprovados, em três das turmas observadas (1995, 1996 e 1997) nas duas escolas avaliadas, categorizados de acordo com a situação final dos alunos

PORCENTAGEM DE ALUNOS

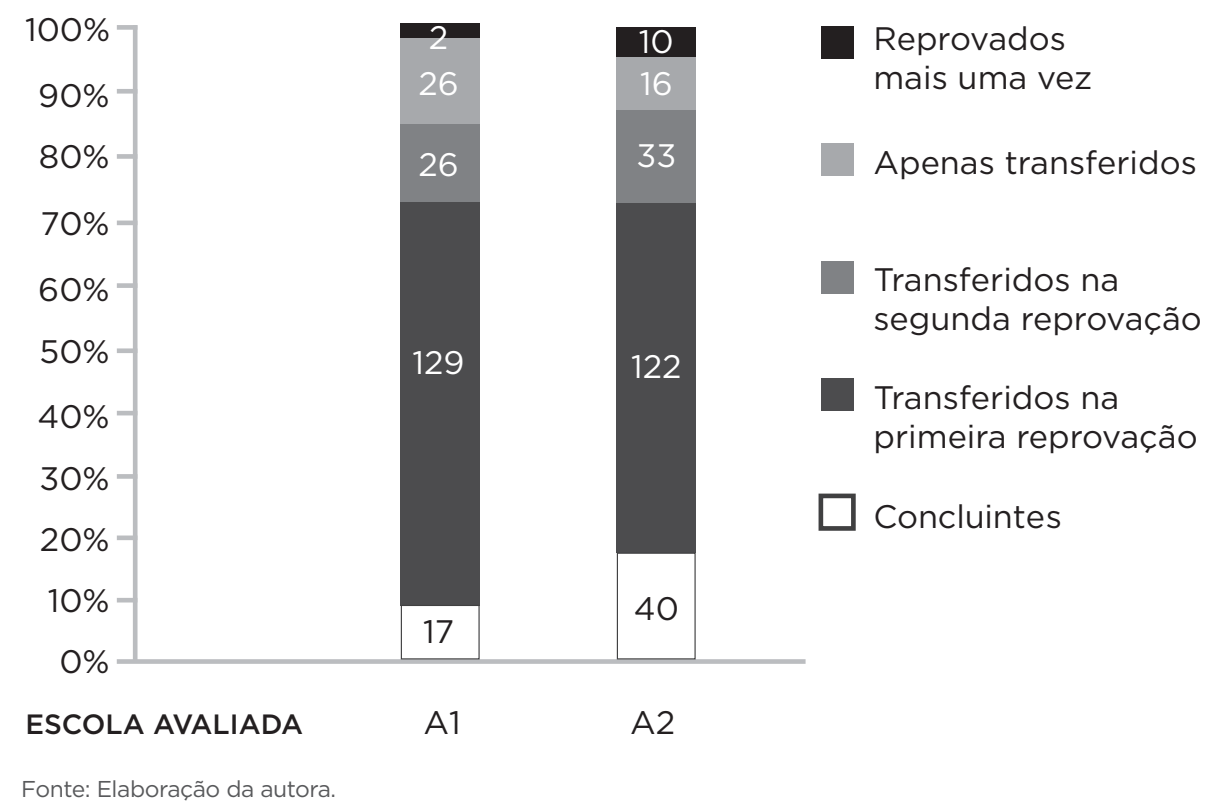




\section{COORTE DE TURMA}

Para realizar a análise, foi escolhido o ano de 1997 da Escola A1 para uma análise exploratória por ser a coorte que teve um número intermediário de formandos que estavam desde a $1^{\mathrm{a}}$ série, como podemos ver na tabela a seguir.

TABELA 3 - Distribuição de frequência dos alunos matriculados na $1^{\text {a }}$ série e dos alunos concluintes, nas quatro turmas observadas na Escola A1

\begin{tabular}{c|cc:cc}
\hline COORTE & ALUNOS NA TaSÉRIE & \multicolumn{2}{|c}{ ALUNOS CONCLUINTES } \\
\hline 1995 & 89 & 22 & $(25 \%)$ \\
1996 & 78 & 31 & $(40 \%)$ \\
1997 & 77 & 28 & $(37 \%)$ \\
1998 & 90 & 34 & $(38 \%)$ \\
\hline
\end{tabular}

Fonte: Elaboração da autora.

Interessante notar que no estudo de Galvão (2003), mencionado na revisão da literatura, a porcentagem de alunos formados na escola sem nenhuma reprovação foi de $27 \%$, portanto um pouco abaixo da encontrada na Escola A1. Como no estudo foi demonstrada a seletividade social feita pela escola, talvez a explicação da diferença esteja por ser por sorteio a forma como os alunos são selecionados no Pedro II para a $1^{\mathrm{a}}$ série. Os alunos da Escola A1 são selecionados socialmente antes de entrar na escola.

Pelo gráfico 10, podemos ver mais uma vez a preponderância das reprovações na $6^{\mathrm{a}}$ e $7^{\mathrm{a}}$ do ensino fundamental e no $1^{\mathrm{o}}$ ano do ensino médio. As transferências ocorrem em maior número nas séries nas quais temos um maior número de reprovações e na $2^{\mathrm{a}}$, na $5^{\mathrm{a}}$ e na $8^{\mathrm{a}}$ série do fundamental. Podemos pensar que na $2^{\mathrm{a}}$ e na $5^{\mathrm{a}}$ os pais decidem mudar o aluno de escola por ver que

19 onvelope de cada aluno continha os contratos de prestação de serviço por ano escolar, uma ficha de matrícula onde constava o endereço e a profissão dos pais. Nos envelopes também estavam os históricos escolares, mas infelizmente não havia mais informações, nem mesmo se os pais eram casados ou não. O cadastro preenchido pelas famílias permanece com o serviço de orientação educacional e não tive acesso a essas informações. talvez o perfil do filho não seja adaptado ao nível de exigência e de disciplina da escola. Na $8^{\mathrm{a}}$ série, como já citado, a transferência se dá provavelmente por uma decisão do aluno em busca de novas experiências escolares. Ou talvez pela percepção de que as suas opções de carreira sejam menos seletivas e por isso o ensino médio da Escola A1 seja exigente demais para as expectativas.

Numa tentativa de ampliar a análise e tentar correlacionar desempenho escolar com origem social dos alunos, foi feito o levantamento dos dados nas fichas dos alunos na secretaria da Escola A1. ${ }^{19}$ 
NÚMERO DE ALUNOS

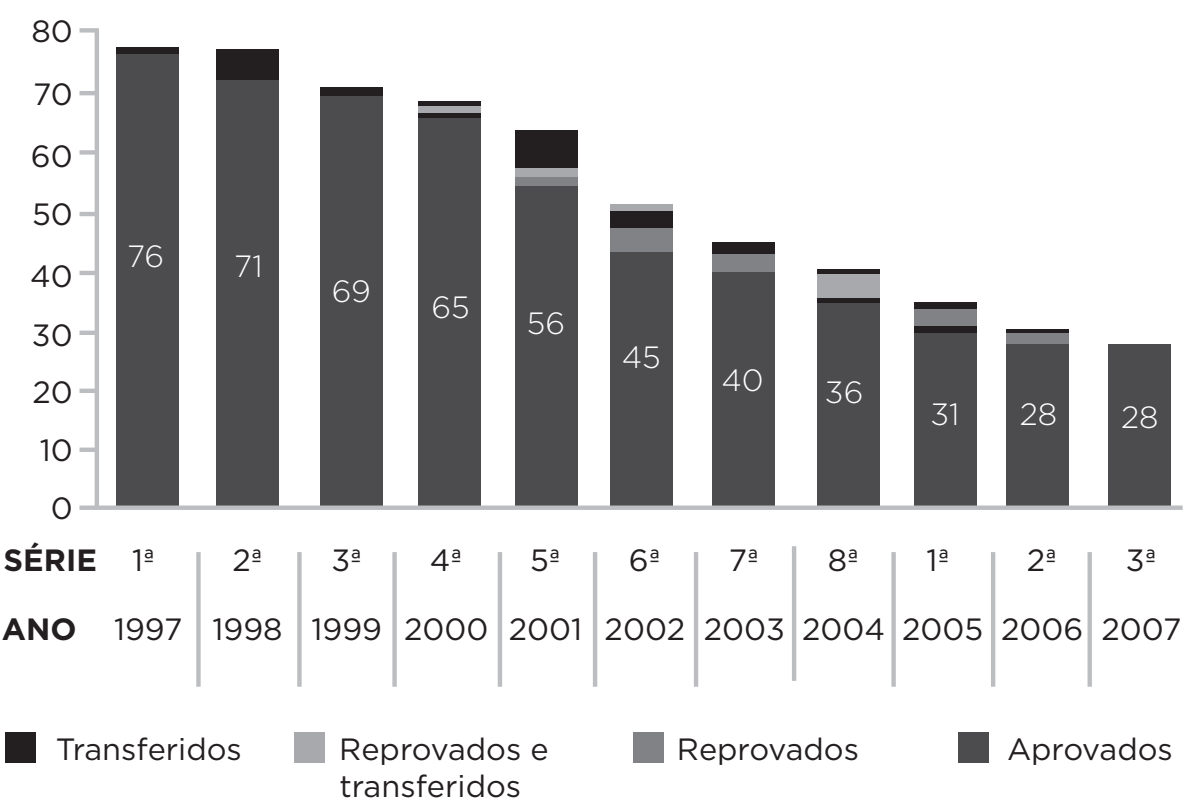

Fonte: Elaboração da autora.

Como análise exploratória, foi usada a informação da zona do bairro de moradia dos alunos como proxy de sua posição social para observar se haveria uma diferença entre os alunos que começaram na $1^{\text {a }}$ série do ensino fundamental daqueles que se formaram no $3^{\circ}$ ano do ensino médio. Assim, tendo em vista a distribuição socioeconômica geográfica do município do Rio de Janeiro, considerou-se que provavelmente os moradores da zona sul teriam o nível socioeconômico mais alto do que a maioria dos moradores das outras zonas. Apesar de os números serem pequenos, a indicação da proporção é interessante para ser investigada. Conforme vemos a seguir, 50\% dos alunos da zona norte se formaram na Escola A1, sendo que os alunos da zona sul foram em menor proporção, com apenas 39\%.

TABELA 4 - Distribuição de frequência dos alunos matriculados na $1^{\text {a }}$ série e dos alunos concluintes, para a turma de 1997 da Escola A1, segundo o local de moradia

\begin{tabular}{|c|c|c|c|c|}
\hline \multirow{2}{*}{$\begin{array}{l}\text { LOCAL DE MORADIA } \\
\text { Zona Sul }\end{array}$} & \multicolumn{2}{|c|}{ ALUNOS NA 1a SÉRIE } & \multicolumn{2}{|c|}{ ALUNOS CONCLUINTES } \\
\hline & 36 & $(47 \%)$ & 11 & (39\%) \\
\hline Zona Norte & 33 & $(43 \%)$ & 14 & $(50 \%)$ \\
\hline Zona Oeste & 7 & $(9 \%)$ & 3 & $(11 \%)$ \\
\hline Itaipu & 1 & $(1 \%)$ & $\mathrm{O}$ & $(\mathrm{O} \%)$ \\
\hline Total & 77 & $(100 \%)$ & 28 & $(100 \%)$ \\
\hline
\end{tabular}

Fonte: Elaboração da autora. 
Talvez possamos imputar essa pequena diferença ao que Bourdieu (2005) chamou de disposição ascética da pequena burguesia (soma norte e oeste), que a transforma na clientela ideal da escola, pois reúne boa vontade cultural e espírito econômico, seriedade e afinco no trabalho, absolutamente necessários ao sucesso da instituição. Já os alunos provenientes da zona sul têm "uma segurança proporcionada pela certeza íntima de poder contar com uma série de "redes de proteção" (BOURDIEU, 2005, p. 95), levando-os a considerar o esforço exigido pela instituição como algo penoso, exagerado, tendo em vista que seu futuro de classe não depende inteiramente dela. Essa segurança faz com que eles possam ter a "audácia" de falhar no projeto escolar. Deve-se salientar, no entanto, que essa foi a única diferença encontrada. Nenhuma outra característica distinguiu os alunos que terminaram em 11 anos, no mesmo estabelecimento, sua trajetória escolar.

\section{EXCELÊNCIA ESCOLAR E SELETIVIDADE}

Emerique (2008), no seu estudo sobre o percurso do conceito "qualidade de ensino", observou que essa seria uma expressão derivada da expansão escolar, enquanto que a excelência acadêmica derivaria de seleção escolar. Diante dos dados podemos considerar, portanto, que de fato qualidade e excelência escolar são expressões que não se confundem. Se as escolas de excelência escolar tivessem o Ideb calculado, perderiam muitos pontos por conta da seletividade escolar operada pela reprovação.

Isso não é uma novidade, tendo em vista a análise de Bourdieu (1989) e aqui no Brasil a pesquisa de Galvão (2003). A diferença que se observa neste trabalho é que são duas instituições privadas, ao contrário das estudadas por Galvão e Bourdieu. Aqui no Brasil, portanto, podemos considerar que

20 Em torno de 470 dólares.

$21 \bigcirc$ envelope de cada aluno De acordo com o depoimento à revista Veja Rio, da educadora Claudia Horta, especialista em preparar alunos para os testes seletivos das melhores escolas do Rio de Janeiro, "um aluno que se apronta para o $2^{\circ}$ ano do Santo Agostinho poderia perfeitamente passar para o 3 de qualquer outro lugar" (apud ALMEIDA, 2009). a seletividade é ainda mais alta, pois começa com o valor das mensalidades. Nem todos podem pagar mais de $\mathrm{R} \$ 900,00^{20}$ por mês, por isso não vemos diferenças na origem social entre os alunos que entram, daqueles que se formam, como pode ser verificado por Galvão (2003).

Além disso, há a prova de nivelamento para entrar no colégio. Os alunos que ingressam em escolas de excelência possuem um repertório acadêmico que lhes permitiria passar para pelo menos um nível acima em outras instituições. ${ }^{21}$ Bourdieu 
considera que a precocidade exigida pelas escolas de excelência permite uma economia do lento trabalho de aquisição que é necessário para alunos medianos, e é "uma das retraduções escolares dos privilégios culturais" (1989, p. 34). ${ }^{22}$ No caso em tela, podemos dizer que a escola seleciona primeiro economicamente e depois culturalmente.

Finalmente, ao longo dos anos, a seleção por desempenho continua com as reprovações. Os dados deixam claro que existem pontos de corte nas escolas, como são os casos da $6^{\mathrm{a}}$, $7^{\mathrm{a}}$ série do ensino fundamental e do $1^{\circ}$ ano do ensino médio. As teorias da reprovação calcadas na personalidade e na capacidade de estudo dos alunos repetentes, de Fourastié (1972) e Ballion (1977), não parecem suficientes. Afinal, no caso da Escola A1, vemos que somente $42 \%$ dos alunos têm o perfil escolar desejado.

Aparentemente, a escola no Brasil é algo para poucos e "bons". Sua atividade principal é separar "o joio do trigo", como disse um coordenador de uma escola tradicional do Rio de Janeiro, com excelentes resultados no Enem. ${ }^{23}$ É claro que em escolas de alto prestígio não se pode ter o mesmo discurso das escolas públicas, não é esse o contrato que com elas é estabelecido, afinal são escolas de elite, logo para poucos.

Pode-se considerar, portanto, que temos aqui um reforço, pelo menos em parte, da tese da "pedagogia da repetência", como denominou Costa Ribeiro. A seletividade escolar tão forte se transforma em marca de qualidade, pois essas são as escolas de prestígio, elas são de alguma forma a imagem do que é considerado padrão em uma escola de excelência na nossa sociedade. Dentro disso, a reprovação maciça de alunos passa a ser um sinônimo de escola puxada, séria, que exige dos alunos uma boa performance. $\mathrm{O}$ contrato é claro: caso o aluno não consiga ter o desempenho esperado, ele será excluído do grupo. Talvez essa seja uma das explicações para que os nossos índices de reprovação sejam tão altos, pois, se esses alunos que, pela literatura em sociologia da educação, possuem todas as características que geralmente conduzem ao sucesso escolar são reprovados nessa proporção, muito mais razão tem a escola pública de reprovar os alunos que estão longe do "ideal”.
22 envelope de cada aluno continha os contratos de prestação de serviço por ano escolar, uma ficha de matrícula onde constava o endereço e a profissão dos pais. Nos envelopes também estavam os históricos escolares, mas infelizmente não havia mais informações, nem mesmo se os pais eram casados ou não. $\bigcirc$ cadastro preenchido pelas famílias permanece com o serviço de orientação educacional e não tive acesso a essas informações.

23 A escola fez parte da pesquisa $O$ efeito escola na produção dos habitus escolares, do grupo Soced/ PUC-Rio, coordenada por Zaia Brandão. 


\section{REFERÊNCIAS}

ALMEIDA, Lívia de. O caminho para a vitória. Veja Rio, Rio de Janeiro, Educação, p. 24-30, 4 nov. 2009.

ALVES, Fátima. Qualidade da educação fundamental: integrando desempenho e fluxo escolar. Ensaio: Aval. Pol. Públ. Educ., Rio de Janeiro, v. 15, n. 57, p. 525-542, out./dez. 2007.

BALLION, Robert. L'Argent et l'école. Paris: Ed. Stock, 1977.

BOURDIEU, Pierre. Futuro de classe e causalidade do provável. In: Escritos de educação. Nogueira, Maria Alice; Catani, Afrânio. Petrópolis, RJ: Vozes, 2005. cap. V, p. 81-126.

. La Noblesse d’État. Paris: Les Éditions de Minuit, 1989.

Os Três estados do capital cultural. In: Escritos de educação. Nogueira, Maria Alice; Catani, Afrânio. Petrópolis, RJ ; Vozes, 2005. cap. IV, p. 70-79.

BRANDÃO, Zaia; LELIS, Isabel. Elites acadêmicas e escolarização dos filhos. Educação \& Sociedade, v. 24, n. 83, p.509-527. ago. 2003.

BROPHY, Jere. Grade repetition. 2006. Paris: Unesco, 2006. (Education policy series, 6).

COSTA RIBEIRO, Sergio. Educação e cidadania. Ensaio: Aval. Pol. Públ. Educ., Rio de Janeiro, v. 1, n. 4, p. 5-22, jul./set. 1994.

. A Pedagogia da repetência. Estudos Avançados, São Paulo, v. 5, n. 12, p. 7-21, maio/ago. 1991.

CRAHAY, Marcel. É possível tirar conclusões sobre os efeitos da repetência? Cadernos de Pesquisa, São Paulo, v. 36, n. 127, p. 223-246, jan./abr. 2006.

Podemos lutar contra o insucesso escolar? Lisboa: Instituto Piaget, 1996.

EMERIQUE, Raquel B. Qualidade de ensino: o percurso de um conceito. Boletim Soced, Rio de Janeiro, n. 5, 2008. Disponível em: <http://www.maxwell.lambda. ele.puc-rio.br/soced.php?strSecao=input>. Acesso em: 25 jan. 2011.

FOURASTIÉ, Jean. Enquête sur la scolarité d'enfants appartenant à des milieux favorisés. Analyse \& Prévision Futuribles, t. 14, n. 1-2, p. 803-831, jul./ago. 1972.

GALVÃO, Maria Cristina da S. A Jubilação no Colégio Pedro II, que exclusão é essa? 2003.190f. Dissertação (Mestrado em Educação) - Faculdade de Educação, UFRJ, Rio de Janeiro, 2003.

JIMERSON, Shane R. Meta-analysis of grade retention research: implications for practice in the 21st century. School Psycology Review, v. 30, n. 3, p. 420-437, 2001.

LAHIRE, Bernard. Sucesso escolar nos meios populares: as razões do improvável. São Paulo: Ática, 1997.

MANDELERT, Diana. Repetência em escolas de prestígio: quanto, quando e como. 2010. 158f. Tese (Doutorado em Educação), Departamento de Educação PUC-Rio, Rio de Janeiro, 2010. 
NOGUEIRA, Maria Alice. A Escolha do estabelecimento de ensino pelas famílias: a ação discreta da riqueza cultural. Revista Brasileira de Educação, n. 7, p. 42-56, jan./abr. 1998.

Favorecimento econômico e excelência escolar: um mito em questão. Revista Brasileira de Educação, nº 26, p. 133-184, maio/ago. 2004.

PAES DE BARROS, Ricardo et al. Determinantes do desempenho educacional no Brasil. Brasília: Ipea, 2001. (Texto para discussão n. 834. n. 7).

PAES DE CARVALHO, Cynthia. Contextos institucionais e escolarização: uma hipótese de classificação das escolas da rede privada de educação básica. Revista Brasileira de Educação, v.11, n. 31, p. 155-201, jan./abr. 2006.

Entre as promessas da escola e os desafios da reprodução social: a família de camadas médias do ensino fundamental à universidade. 2004. 317f. Tese (Doutorado em Educação), Departamento de Educação. - PUC-Rio, Rio de Janeiro, 2004.

RODRIGUES, Gizelli. A Reprovação escolar e suas repercussões no cotidiano de famílias das camadas médias. 2004. 122 f. Dissertação (Mestrado em Educação) - Centro de Ciências da Educação, Universidade Federal de Santa Catarina, Florianópolis, 2004.

SALOMON, Maria Luisa de O. Alguns mecanismos de produção de percursos escolares acidentados nos meios sociais favorecidos. 2001. 250f. Dissertação (Mestrado em Educação), Faculdade de Educação, PUC-MG, Belo Horizonte, 2001.

SOUZA, Alberto de M.; SILVA, Nelson do V. Origem familiar, qualidade da educação e escolas públicas e particulares em São Paulo: relações e efeitos nas transições escolares. Pesq. Plan. Econ., Rio de Janeiro, v. 24, n. 1, p. 97-114, abr. 1994.

\section{DIANA MANDELERT}

Professora da Faculdade de Educação da USP. Integrante do grupo de pesquisa Soced - PUC/RJ dmandelert@gmail.com 